\title{
RIFLE serum creatinine and urine output criteria combined is superior to RIFLE serum creatinine criterion alone in predicting Acute Kidney Injury (AKI) in critically ill patients: A prospective observational study
}

Amina Sultana ${ }^{1 *}$, Mohammad Omar Faruq², A.S.M. Areef Ahsan³, Uzzwal Kumar Mallick, Mohammad Asaduzzaman $^{4}$, Md Motiul Islam ${ }^{5}$

\begin{abstract}
:
Background: Approximately 7\% of all hospitalized patients and 20\% of acutely ill patients develop signs of AKI. AKI incidence is very high worldwide among intensive care unit patients. Previously long known term, acute renal failure $(A R F)$ is largely replaced by acute kidney injury (AKI), reflecting the recognition that smaller decrements in kidney function that do not result in overt organ failure are of substantial clinical relevance and are associated with increased morbidity and mortality.

Objectives: We designed this study to diagnose even mild renal dysfunction earlier than usual time frame with the combined effect of both serum creatinine and urine output criteria, when compared with serum creatinine criterion alone. To establish this objective we used RIFLE serum creatinine and urine output (UO) criteria combined ( $\left.S_{c r+} U O\right)$ and compared with RIFLE serum creatinine ( $S_{c r}$ ) alone to diagnose AKI early (in days).
\end{abstract}

Design: Prospective observational cohort study. Duration of the study was one year (01 year), from January 2014 to December 2014

Method: All adult patients admitted into department of critical care medicine, BIRDEM General Hospital, DHAKA who received treatment for 48 hours and fulfilled the inclusion and exclusion criteria was included in the study. Representative serum creatinine value was obtained either from the day of admission in hospital, day of admission into or transfer to ICU or any document within last six months. The lesser of pre-ICU admission serum creatinine $\left(S_{C}\right)$ and ICU admission $S_{C r}$ would serve as baseline renal function. Weight in kilogram, representative serum urea/BUN, co-morbidities and reason for ICU admission were incorporated in it. Patient's daily data entry of renal replacement therapy, daily creatinine value, urinary output over 6 hours, 12 hours, and 24 hours, episode of anuria over 12 hours, if present were documented. Data collected on renal replacement therapy at the time of discharge, if any and outcome in terms of loss and ESRD status were collected. APACHE II data and SAPS II data were calculated and analyzed.

Result: Total 236 adult patients were enrolled in the study to assess their renal function status using RIFLE (Risk, Injury, Failure, Loss, End Stage Renal Disease). Serum creatinine was estimated daily for seven days. Those patients who fulfilled the creatinine criteria for RIFLE were categorized into RIFLE serum creatinine $\left(S_{c}\right)$ group. Those patients who met both the criteria for urine output and serum creatinine according to RIFLE was designated as RIFLE serum creatinine and urine output criteria Combined $\left(S_{c r}+U O\right)$ group.

In our study, mean of number of days needed for diagnosis of AKI using RIFLE creatinine $\left(S_{c r}\right)$ was $3.25( \pm 1.24)$ and using RIFLE combined ( $S_{c r}+$ uo) criteria was 2.84( \pm 1.03$)$.

Conclusion: The present study concludes that RIFLE serum creatinine criterion $\left(S_{c}\right)$ alone delays the diagnosis of $A K I$ in comparison to RIFLE serum creatinine and urine output criteria combined $\left(S_{c r}+U O\right)$. AKI should be graded using both the criteria of RIFLE serum creatinine and urine output criteria combined $\left(S_{c r}+U O\right)$. Urine output should not be underestimated in AKI diagnosis in ICU patients.

Key words: Acute kidney injury (AKI), RIFLE criteria.

\section{Introduction:}

Acute kidney injury (AKI) indicates abrupt loss of kidney function, resulting in the retention of urea and other nitrogenous waste products and in the dysregulation of extracellular volume and electrolytes. It is often reversible loss of renal function, which develops over days or weeks and is usually accompanied by reduction in urine output. Approximately $7 \%$ of all hospitalized patients and 20\% of acutely ill patients develop signs of AKI. AKI incidence is very high worldwide among intensive care unit patients ${ }^{1}$.In uncomplicated AKI such as that due to hemorrhage or drugs, mortality is low, even when renal replacement therapy is needed. In AKI associated with serious infection and multiple organ failure, mortality rate is very high. Previously known term, acute renal failure (ARF) is largely replaced by acute kidney injury (AKI), reflecting the recognition that smaller decrements in kidney function that do not result in overt organ failure are of substantial clinical relevance and are associated with increased morbidity and mortality. The term ARF is now reserved for severe AKI, usually implying the need for renal replacement therapy. 
Among many there are two common ways of classifying AKI being practiced now a days. One is RIFLE criteria which is the acronym for Risk, Injury, Failure, Loss of function and End stage renal disease (ESRD). ${ }^{2}$ The second way of classifying AKI which is Acute Kidney Injury Network (AKIN 1,2\& 3$)^{2}$

Measurement of serum creatinine is the most widely used measure of renal function in all classification system. The diagnostic usefulness of serum creatinine as an indicator of glomerular filtration rate (GFR) is based upon its constant production from muscle creatine and its relatively constant renal excretion rate.

But serum creatinine is a crude indicator of renal disease. Moderate changes in GFR may not be detected by serum creatinine levels. A change in serum creatinine from 0.6 to 1.2 $\mathrm{mg} / \mathrm{dL}$ reflects a $50 \%$ decline in GFR, even though creatinine is still within the normal range.

Serum creatinine is subjected to change to some body condition e.g. it decreased in individuals with small stature, cachexia, amputations, or muscle disease. Advanced liver disease causes low serum creatinine because of decreased hepatic conversion of creatine to creatinine, decreased dietary protein intake, muscle wasting, and increased renal tubular secretion of creatinine. Patients with liver disease may have a normal serum creatinine even though creatinine clearance is less than $60 \mathrm{~mL} / \mathrm{min}$. Elderly patients have decreased muscle mass and decreased creatinine production. Creatinine levels are reduced during pregnancy because of increased GFR. So serum creatinine is not always an ideal marker for rapid and accurate diagnosis of acute kidney injury, especially in critically ill patients.

Another relevant question is whether urine output criterion can be included in assessing AKI. If urine output is included, some patients may be classified at a high stage of severity and by including measurements of urine output both diagnosis and staging may be made faster. However, few patients will exhibit changes in urine output sufficient for the diagnosis of AKI but never manifest a change in creatinine criteria. These groups of patients are almost exclusively RIFLE-R (AKIN Stage 1) and seem to have a low mortality (though often not

1 Associate Consultant, GICU and ED, United Hospital Limited, Dhaka.

2 Professor and Chief Consultant, GICU, ED and Covid Isolation unit, United Hospital, Dhaka.

3 Professor Critical Care Medicine, Birdem Hospital, Dhaka.

4 Assist Professor, ICU, National Institute of Neuroscience Hospital, Dhaka.

5 Associate Consultant and In charge of ICU, Asgar Ali Hospital, Dhaka.

\section{*Corresponding Author:}

Dr. Amina Sultana

MBBS, MD (CCM)

Associate Consultant, GICU and ED, United Hospital Limited,

Dhaka 1212, Bangladesh

Email: aminasultana95@yahoo.com

Contact: +8801732955192 quite as low as patients without any AKI criteria). Exclusion of these patients from a diagnosis of AKI is tempting. A low urine output is an entirely appropriate response of the kidney to a reduced intravascular volume and given that these patients never manifest an increase in serum creatinine levels it would seem inappropriate to diagnose them as having AKI. Whether these patients were prevented from developing more severe AKI because they received appropriate care triggered by the onset of oliguria is, however, unknown. Indeed, the majority of patients who fulfil urine output criteria will also, eventually, fulfil criteria for serum creatinine levels ${ }^{3}$.

A rise in creatinine is a late sign of kidney damage; therefore it cannot be a reliable indicator of acute changes in kidney function. Discovery of a predictor biomarker of acute kidney injury would be of great value. The response over a few years resulted in the identification of nearly 20 potential markers reported in nearly 120 articles of varying quality attempting to validate the utility of markers in human AKI. Some of the more promising of these include either urine or plasma neutrophil gelatinase-associated lipocalin (NGAL) ${ }^{4}$ kidney injury molecule-1 (KIM-1) ${ }^{5}$ IL-18, ${ }^{6}$ cystatin C ${ }^{7}$ liver fatty-acid binding protein (L-FABP), ${ }^{8}$ IL- $6^{9} \alpha / \pi$ glutathione S-transferase (GST) ${ }^{10}$ and N-acetyl- $\beta$-d-glucosaminidase (NAG) ${ }^{11}$.

Newer biomarkers are not widely available, are expensive, and most importantly, many of them are yet to be proven statistically. So, we tried to construct a simple, easy to use and useful predictor of AKI. We have designed a study which will use the combined effect of rise of serum creatinine and fall of urine output to predict the early diagnosis of AKI in ICU patients. Individually both the criteria are useful in diagnosis of AKI. Many studies used one or other of them to diagnose AKI. Few studies did not use urine output criteria for their inconvenience. Few other studies tested their usefulness by comparison among both the criteria. We desired to observe the combined effect of both serum creatinine and urine output criteria, in comparison to serum creatinine criteria alone. The objective of this study is to determine that AKI in early stage of RIFLE (Risk) can be diagnosed earlier by using combined method rather than using serum creatinine alone.

\section{Materials and Method:}

This Prospective observational study was conducted in department of Critical Care Medicine in BIRDEM General Hospital, Dhaka during the period of January 2014 to December 2014. Two hundred and thirty six adult (Age $\geq$ 18years) consecutive patients admitted in department of critical care medicine, BIRDEM General Hospital, DHAKA and who received treatment for 48 hours were included in the study. Exclusion criteria were patients whose baseline serum creatinine criteria was not known, anuria due to obstructive uropathy, patient on chronic renal replacement therapy (RRT), patient admitted after recent kidney transplant, ICU discharge or death before 48 hours of admission . Readmission to the ICU during the same hospitalization episode was also included in the study.

All enrolled study patients were assessed for their renal function status using RIFLE (Risk, Injury, Failure, Loss, End Stage 
Renal Disease). Every patient enrolled in the study were subjected to testing with serum creatinine criteria $\left(\mathrm{S}_{\mathrm{cr}}\right)$ and combined criteria $\left(\mathrm{S}_{\mathrm{cr}}+\mathrm{UO}\right)$ and categorized as $\mathrm{AKI}\left(\mathrm{S}_{\mathrm{cr}}\right)$ and $\mathrm{AKI}\left(\mathrm{S}_{\mathrm{cr}}+\mathrm{UO}\right)$ and non AKI $\left(\mathrm{S}_{\mathrm{cr}}\right)$ and non AKI $\left(\mathrm{S}_{\mathrm{cr}}+\mathrm{UO}\right)$ groups. Serum creatinine was estimated daily for seven days $\left(D_{0}, D_{1}\right.$, $D_{2}, D_{3}, D_{4}, D_{5}$ and D6). Those patients who fulfilled the creatinine criteria for RIFLE were categorized into RIFLE serum creatinine $\left(\mathrm{S}_{\mathrm{cr}}\right)$ group. This group is further subdivided into RIFLE $\mathrm{S}_{\text {cr }}$ Risk (serum creatinine increased $\geq 1.5$ from baseline), Injury (serum creatinine increased $\geq 2.0$ from baseline), Failure (serum creatinine increased $\geq 3.0$ from baseline) according to equal distribution of available serum creatinine. Urine output is measured hourly since first hour of ICU admission.

Those patients who met both the criteria for urine output and serum creatinine according to RIFLE was designated as RIFLE serum creatinine and urine output criteria combined $\mathrm{S}_{\mathrm{cr}}+\mathrm{UO}$ (Urine Output) group. This group was further subdivided into RIFLE $\left(\mathrm{S}_{\mathrm{cr}}+\mathrm{UO}\right)$ Risk (serum creatinine increased $\geq 1.5$ from baseline and/or urine output $<0.5 \mathrm{ml} / \mathrm{kg} / \mathrm{h}$ $\geq 6 \mathrm{~h}$ ), RIFLE ( $\mathrm{S}_{\mathrm{cr}}+\mathrm{UO}$ ) Injury (serum creatinine increased $\geq$ 2.0 from baseline and/or urine output $<0.5 \mathrm{ml} / \mathrm{kg} / \mathrm{h} \geq 12 \mathrm{~h}$ ), RIFLE $\left(\mathrm{S}_{\mathrm{cr}}+\mathrm{UO}\right)$ Failure (serum creatinine increased $\geq 3.0$ from baseline and/or urine output $<0.3 \mathrm{ml} / \mathrm{kg} / \mathrm{h} \geq 24 \mathrm{~h}$ ). Urine output was measured hourly since first hour of ICU admission.

Both the groups were compared to see which group can detect acute kidney injury earlier in terms of days.

Detailed history and physical examination was done and required data were recorded in preformed data collection sheet. On admission patient identification and registration data was incorporated in each case record form. Representative serum creatinine value was obtained either from the day of admission in hospital, admission in, or transfer to ICU or any document within last three months. The lesser of pre-ICU admission serum creatinine $\left(\mathrm{S}_{\mathrm{Cr}}\right)$ and ICU admission serum creatinine $\left(\mathrm{S}_{\mathrm{Cr}}\right)$ served as baseline renal function. Weight in kilogram, representative serum urea/BUN, co-morbidities and reason for ICU admission were incorporated in it. SOFA score ${ }^{12}$ data were collected from AKI patients, 24 hours preceding AKI diagnosis. These includes serum creatinine (highest value), urine output ( $\mathrm{ml} /$ day) (lowest value), platelet (highest value), total bilirubin (highest value), mechanical ventilation, $\mathrm{PaO}_{2} / \mathrm{FiO}_{2}$, mean arterial pressure (lowest value), vasopressors (highest value), and Glasgow Coma Scale (lowest value). Data collected on renal replacement therapy at the time of discharge, if any. Data received on outcome in terms of loss and ESRD status. Informed consent were taken from all the study subjects or from the legal guardians before enrolling them in the study. All the patients selected as study subjects were evaluated for demographic profile (age, sex). Risk factors for coronary artery disease like diabetes, hypertension, dyslipidemia, smoking, obesity and family history of premature CAD was recorded. Baseline investigation e.g. ECG, troponin I, fasting lipid profile, fasting blood sugar (FBS) were done for each patient. All the information were properly noted in the preformed data collection sheet.

APACHE II scoring was done using MDcalc ${ }^{13}$ (Age in years, temperature in Celsius, mean arterial pressure $\mathrm{mm}$ of $\mathrm{Hg}, \mathrm{p}^{\mathrm{H}}$, Heart rate per minute, respiratory rate per minute, sodium $\mathrm{mmol} / \mathrm{L}$, potassium $\mathrm{mmol} / \mathrm{L}$, creatinine $\mathrm{mg} / \mathrm{dl}$, respiratory rate per minute, WBC per $\mathrm{mm}^{3}$, GCS, FiO2.

SAPS II was designed to measure the severity of disease for patients admitted to Intensive care units aged 18years or more. ${ }^{14} 24$ hours after admission to the ICU, the measurement has been completed and resulted in an integer point score between 0 and 163 and a predicted mortality between $0 \%$ and $100 \%$. No new score can be calculated during the stay. If a patient is discharged from the ICU and readmitted, a new SAPS II score can be calculated. The point score is calculated from 12 routine physiological measurements during the first 24 hours, information about previous health status and some information obtained at admission. The parameters are (Age, Heart Rate, Systolic Blood Pressure, Temperature, Glasgow Coma Scale, Mechanical Ventilation or CPAP, PaO2, FiO2, Urine Output, Blood Urea Nitrogen, Sodium, Potassium, Bicarbonate, Bilirubin, White Blood Cell, Chronic diseases, Type of admission.

Data were analyzed by using SPSS version 17. Categorical data were expressed as frequency and percentage and continuous data was expressed as mean $\pm \mathrm{SD}$. Comparison of categorical data between groups was done Chi- square test. The comparison of mean between two groups was done by Student's $t$ test. The level of significance was set at 0.05 .

Ethical approval was taken from the "Research Review Committee" \& the "Ethical Committee" of BIRDEM General Hospital, Dhaka.

Result: Two hundred thirty six adult patients were enrolled in the study. The descriptive and inferential statistics are described below from Table 1 to Table XIII respectively.

Table 1 : Comparison of baseline characteristics in both the groups

\begin{tabular}{lcccc}
\hline & $\begin{array}{c}\text { All } \\
\mathrm{N}=236\end{array}$ & $\begin{array}{c}\text { RIFLE serum } \\
\text { Creatinine }\left(\mathrm{S}_{\mathrm{cr}}\right) \\
\mathrm{N}=118\end{array}$ & $\begin{array}{c}\text { RIFLE Combined } \\
\left(\mathrm{S}_{\mathrm{cr}}+\mathrm{UO}\right) \\
\mathrm{N}=188\end{array}$ & $\mathrm{p}-\mathrm{value}$ \\
\hline Age in years & $61.55( \pm 13.95)$ & $62.73( \pm 12.12)$ & $59.58( \pm 14.32)$ & 0.04 \\
Male & $138(58.5)$ & $70(59.3)$ & $107(56.9)$ & 0.67 \\
Female & $98(41.5)$ & $48(40.7)$ & $81(43.1)$ & \\
\hline
\end{tabular}


Bangladesh Crit Care J March 2020; 8 (1): 17-23

\begin{tabular}{|c|c|c|c|c|}
\hline Weight & $61.62( \pm 7.47)$ & $61.71( \pm 7.09)$ & $61.46( \pm 7.66)$ & 0.77 \\
\hline Height & $160.19( \pm 7.38)$ & $161.26( \pm 7.74)$ & $160.57( \pm 7.48)$ & 0.43 \\
\hline Pre-ICU admission serum creatinine & $1.75( \pm 1.30)$ & $1.78( \pm 1.10)$ & $1.66( \pm 1.2)$ & 0.38 \\
\hline ICU admission serum creatinine & $2.95( \pm 2.58)$ & $4.01( \pm 2.87)$ & $3.10( \pm 2.68)$ & 0.005 \\
\hline APACHE II & $21(8)$ & $21(7)$ & $21(9)$ & \\
\hline SAPS & $52(17)$ & $54(16)$ & $50(17)$ & \\
\hline ICU stay & $5.19(3.13)$ & $5.44(3.44)$ & $5.26(3.18)$ & 0.64 \\
\hline
\end{tabular}

Table Il : Mean day of diagnosis of AKI

\begin{tabular}{llll}
\hline & Mean day of RIFLE creatinine $\left(\mathrm{S}_{\mathrm{cr}}\right)$ AKI & Mean day of RIFLE combined $\left(\mathrm{S}_{\mathrm{cr}}+\mathrm{uo}\right)$ AKI & $\mathrm{p}-\mathrm{value}$ \\
\hline Mean $\pm \mathrm{SD}$ & $3.25( \pm 1.24)$ & $2.84( \pm 1.03)$ & $<0.001$ \\
\hline
\end{tabular}

Table III : Diagnosing AKI using combined criteria

\begin{tabular}{lccc}
\hline Number of Days & $\begin{array}{c}\text { AKI } \\
\mathbf{n}(\%)\end{array}$ & $\begin{array}{c}\text { Combined } \\
\text { Non AKI } \\
\mathbf{n}(\%)\end{array}$ & Total \\
\hline Day-0 & $188(79.7 \%)$ & $48(20.3 \%)$ & 236 \\
Day-1 & $126(53.4 \%)$ & $110(46.6 \%)$ & 236 \\
Day-2 & $123(53.0 \%)$ & $109(47.0 \%)$ & 232 \\
Day-3 & $93(51.4 \%)$ & $88(48.6 \%)$ & 181 \\
Day-4 & $70(58.3 \%)$ & $50(41.7 \%)$ & 120 \\
Day-5 & $97(96.0 \%)$ & $04(4 \%)$ & 101 \\
Day-6 & $91(93.8 \%)$ & $06(6.2 \%)$ & 97 \\
\hline
\end{tabular}

Table IV : Diagnosing AKI, combined $\left(\mathrm{S}_{\mathrm{Cr}}+\mathrm{UO}\right)$ vs. S. creatinine

\begin{tabular}{lcccc}
\hline No of days Combined & $\begin{array}{c}\text { AKI } \\
\mathbf{n}(\%)\end{array}$ & $\begin{array}{c}\text { Creatinine } \\
\text { AKI } \\
\mathbf{n}(\%)\end{array}$ & Total & p- value \\
\hline Day-0 & $188(79.7 \%)$ & $118(50 \%)$ & 236 & $<0.001$ \\
Day-1 & $126(53.4 \%)$ & $112(47.5 \%)$ & 236 & 0.19 \\
Day-2 & $123(53.0 \%)$ & $107(46.1 \%)$ & 232 & 0.13 \\
Day-3 & $93(51.4 \%)$ & $77(42.5 \%)$ & 181 & 0.09 \\
Day-4 & $70(58.3 \%)$ & $61(50.8 \%)$ & 120 & 0.24 \\
Day-5 & $97(96.0 \%)$ & $97(96.0 \%)$ & 101 & 1.0 \\
Day-6 & $91(93.8 \%)$ & $91(93.8 \%)$ & 97 & 1.0 \\
\hline
\end{tabular}

Table V : Diagnosing Non AKI, combined $\left(\mathrm{S}_{\mathrm{Cr}}+\mathrm{UO}\right) \mathrm{vs.}$ S. creatinine

\begin{tabular}{lcccc}
\hline No of days Combined & $\begin{array}{c}\text { Creatinine } \\
\text { AKI } \\
\text { n(\%) }\end{array}$ & $\begin{array}{c}\text { AKI } \\
\mathbf{n}(\%)\end{array}$ & Total & p-value \\
\hline Day-0 & $48(20.3 \%)$ & $118(50 \%)$ & 236 & $<\mathbf{0 . 0 0 1}$ \\
Day-1 & $110(46.6 \%)$ & $124(52.5 \%)$ & 236 & 0.19 \\
Day-2 & $109(47.0 \%)$ & $125(53.9 \%)$ & 232 & 0.13 \\
Day-3 & $88(48.6 \%)$ & $104(57.5 \%)$ & 181 & 0.09 \\
Day-4 & $50(41.7 \%)$ & $59(49.2 \%)$ & 120 & 0.24 \\
Day-5 & $04(4 \%)$ & $04(4 \%)$ & 101 & 1.0 \\
Day-6 & $06(6.2 \%)$ & $06(6.2 \%)$ & 97 & 1.0 \\
\hline
\end{tabular}

Table VI: Severity grades combined $\left(\mathrm{S}_{\mathrm{Cr}}+\mathrm{UO}\right)$ vs. creatinine

\begin{tabular}{lccc}
\hline Severity grade & $\begin{array}{c}\text { RIFLE } \\
\text { Combined } \\
\left(\mathbf{S}_{\text {cr }}+\mathbf{U}\right) \\
\mathbf{n}(\%)\end{array}$ & $\begin{array}{c}\text { RIFLE } \\
\text { serum } \\
\text { creatinine }\left(\mathbf{S}_{\text {cr }}\right)\end{array}$ & p-value \\
$\mathbf{n}(\%)$ & \\
\hline Non AKI & $48(20.33 \%)$ & $118(50 \%)$ & $<0.001$ \\
AKI-R & $188(79.7 \%)$ & $118(50 \%)$ & $<0.001$ \\
AKI-I & $166(70.3 \%)$ & $65(27.5 \%)$ & $<0.001$ \\
AKI-F & $64(27.1 \%)$ & $15(6.4 \%)$ & $<0.001$ \\
\hline
\end{tabular}

Table VIl : Outcome of creatinine AKI and Non AKI

RIFLE serum creatinine $\left(S_{C r}\right)$ Outcome Total p value

\begin{tabular}{lcccc} 
& Alive & Dead & & \\
\hline Non -AKI & 84 & 34 & 118 & 0.48 \\
AKI & 79 & 39 & 118 & \\
Total & 163 & 73 & 236 & \\
\hline
\end{tabular}


Table VIll : Outcome of combined AKI(S ${ }_{\mathrm{Cr}}+$ UO) and Non AKI

\begin{tabular}{lcccc}
\hline RIFLE combined & \multicolumn{2}{c}{ Outcome } & \multirow{2}{*}{ Total } & p value \\
\cline { 2 - 3 }$\left(\mathbf{S}_{\text {er }}+\mathbf{U O}\right)$ & Alive & Dead & & \\
\cline { 2 - 3 } & 133 & 55 & 188 & 0.27 \\
\hline Non -AKI & 30 & 18 & 48 & \\
AKI & 163 & 73 & 236 & \\
Total & & & & \\
\hline
\end{tabular}

Table IX : Mortality rates in combined $\left(\mathrm{S}_{\mathrm{Cr}}+\mathrm{UO}\right) \mathrm{AKI}$ and Non AKI, Combined S. creatinine AKI and Non AKI groups

\begin{tabular}{lcccc}
\hline & Alive & Dead & Total no. & $\begin{array}{c}\text { Mortality } \\
\text { rate }\end{array}$ \\
\hline $\begin{array}{l}\text { RIFLE Combined } \\
\left(\mathrm{S}_{\text {cr }}+\mathrm{UO}\right) \text { AKI }\end{array}$ & 133 & 55 & 188 & $\mathbf{2 3 . 3 0 \%}$ \\
$\begin{array}{l}\text { RIFLE serum } \\
\text { creatinine }\left(\mathrm{S}_{\mathrm{Cr}}\right) \text { AKI }\end{array}$ & 79 & 39 & 118 & $\mathbf{1 6 . 5 2 \%}$ \\
$\begin{array}{l}\text { RIFLE Combined } \\
\left(\mathrm{S}_{\mathrm{Cr}}+\mathrm{UO}\right) \text { Non- AKI }\end{array}$ & 30 & 18 & 48 & $\mathbf{7 . 6 2 \%}$ \\
$\begin{array}{l}\text { RIFLE serum } \\
\text { creatinine }\left(\mathrm{S}_{\mathrm{Cr}}\right) \text { Non-AKI }\end{array}$ & 84 & 34 & 118 & $\mathbf{1 4 . 4 0 \%}$ \\
\hline
\end{tabular}

Table :X : Mortality rates among AKI and Non AKI

\begin{tabular}{lccc}
\hline & \multicolumn{2}{c}{ Mortality } & p value \\
& $\begin{array}{c}\text { RIFLE } \\
\text { Combined } \\
\left(\mathbf{S}_{\text {cr }}+\text { UO) }\right.\end{array}$ & $\begin{array}{c}\text { RIFLE } \\
\text { serum } \\
\text { creatinine } \\
\left(\mathbf{S}_{\text {cr }}\right)\end{array}$ & \\
\hline AKI & 55 & 39 & $\mathbf{0 . 0 0 0 3}$ \\
Non-AKI & 18 & 34 & \\
Total & 73 & 73 & \\
\hline
\end{tabular}

Table :XI : Hydration status in creatinine and combined AKI groups

\begin{tabular}{lcccc}
\hline $\begin{array}{l}\text { Fluid balance All } \\
\text { N=236 }\end{array}$ & $\begin{array}{c}\text { RIFLE } \\
\text { serum } \\
\text { creatinine } \\
\left(\mathbf{S}_{\text {cr }} \text { ) AKI }\right. \\
\mathbf{n = 1 1 8}\end{array}$ & $\begin{array}{c}\text { RIFLE } \\
\text { Combined } \\
\left.\mathbf{S}_{\text {cr }}+\mathbf{U} \mathbf{1 1}\right)\end{array}$ & $\begin{array}{c}\text { AKI } \\
\mathbf{n = 1 8 8}\end{array}$ & \\
\hline Positive & 184 & $99(83.9 \%)$ & $145(77.13 \%)$ & 0.15 \\
Negative & 52 & $19(16.1 \%)$ & $43(22.87 \%)$ & 0.15
\end{tabular}

Table :XII : Co morbidities in creatinine and combined AKI groups

\begin{tabular}{lcccc}
\hline & All & $\begin{array}{c}\text { RIFLE } \\
\text { serum } \\
\text { creatinine } \\
\left(\mathbf{S}_{\mathbf{c r}}\right)\end{array}$ & $\begin{array}{c}\text { RIFLE } \\
\text { Combined } \\
\left.\mathbf{( S}_{\mathbf{c r}}+\mathbf{U O}\right)\end{array}$ & p- value \\
\hline Cancer & 05 & -- & $05(100 \%)$ & 0.001 \\
Hypertension & 163 & $93(57.06 \%)$ & $139(85.28 \%)$ & $<\mathbf{0 . 0 0 1}$ \\
$\begin{array}{l}\text { Chronic heart } \\
\text { failure (NYHA 1V) }\end{array}$ & 17 & $04(23.53 \%)$ & $04(23.53 \%)$ & 1.0 \\
$\begin{array}{l}\text { Diabetes mellitus } \\
\text { 189 }\end{array}$ & $105(55.56 \%)$ & $154(81.48 \%)$ & $<0.001$ \\
$\begin{array}{l}\text { Use of vasoactive } \\
\text { drug before ICU }\end{array}$ & 06 & $05(83.3 \%)$ & $06(100 \%)$ & 1.0 \\
\begin{tabular}{l} 
admission \\
\hline
\end{tabular} & & & & \\
\hline
\end{tabular}

Table :XIII : Etiology of AKI in creatinine and combined AKI groups

\begin{tabular}{|c|c|c|c|c|}
\hline & $\underset{\mathbf{N}=\mathbf{2 3 6}}{\text { All }}$ & $\begin{array}{c}\text { RIFLE } \\
\text { serum } \\
\text { creatinine } \\
\left(\mathrm{S}_{\mathrm{cr}}\right) \text { AKI } \\
\mathrm{n}=118\end{array}$ & $\begin{array}{c}\text { RIFLE } \\
\text { Combined } \\
\left.\text { (S } \mathrm{S}_{\text {cr }}+\mathrm{UO}\right) \\
\text { AKI } \\
\mathbf{n}=\mathbf{1 8 8}\end{array}$ & p value \\
\hline Drug induced & $50(22.8 \%)$ & $27(20.7 \%)$ & $39(21.2 \%)$ & 0.65 \\
\hline Sepsis & $145(77.9 \%)$ & $92(65.4 \%)$ & $123(61.4 \%)$ & 0.01 \\
\hline Hypovolemia & $85(44.9 \%)$ & $53(37.8 \%)$ & $71(36.1 \%)$ & 0.21 \\
\hline $\begin{array}{l}\text { Cardiogenic } \\
\text { shock }\end{array}$ & $17(9.3 \%)$ & $11(6.4 \%)$ & $12(7.2 \%)$ & 0.34 \\
\hline $\begin{array}{l}\text { Hepato-renal } \\
\text { syndrome }\end{array}$ & $06(3.4 \%)$ & $4(2.7 \%)$ & $05(2.5 \%)$ & 1.0 \\
\hline Other & $32(19.5 \%)$ & $23(14.4 \%)$ & $27(13.6 \%)$ & 0.23 \\
\hline
\end{tabular}

\section{Discussion:}

In our patients, baseline characteristics were compared in both the groups (Table 1). Age of the patients in both groups had no significant difference, mean age of all the patients were (mean $\pm \mathrm{SD}), 61.55( \pm 13.95)$, in RIFLE $\mathrm{S}_{\mathrm{Cr}}$ it was $62.73( \pm 12.12)$, in RIFLE $\mathrm{S}_{\mathrm{Cr}}+\mathrm{UO}, 59.58( \pm 14.32)$. Mean baseline serum creatinine, (mean $\pm \mathrm{SD}$ ) is1.75 $( \pm 1.30)$ in all patients, 1.78 $( \pm 1.10)$ in RIFLE $\mathrm{S}_{\mathrm{Cr}}$ and1.66 $( \pm 1.2)$ in RIFLE $\mathrm{S}_{\mathrm{Cr}}+\mathrm{UO}$, there is statistically significant difference in the mean of pre-ICU serum creatinine values between the groups. Whereas (mean $\pm \mathrm{SD})$ of ICU admission serum creatinine is $2.95( \pm 2.58)$ in all patients, it is $4.01( \pm 2.87)$ in RIFLE $\mathrm{S}_{\mathrm{Cr}}$ and $3.10( \pm 2.68)$ in RIFLE $\mathrm{S}_{\mathrm{Cr}}+\mathrm{UO}, \mathrm{p}$ - value 0.005 , significant. Mean length of ICU stay (mean $\pm \mathrm{SD}$ ) is $5.19( \pm 3.13)$, that of RIFLE $\mathrm{S}_{\mathrm{Cr}}+\mathrm{UO}$ group is $5.44( \pm 3.44)$ and of RIFLE $\mathrm{S}_{\mathrm{Cr}}$ is5.26 $( \pm 3.18)$. We did not observe statistically significant difference in length of ICU stay among the RIFLE $\mathrm{S}_{\mathrm{Cr}}+\mathrm{UO}$ and RIFLE $\mathrm{S}_{\mathrm{Cr}}$ groups.

Table 11 shows comparison of mean time in days needed to 
diagnose AKI in both the groups, it is $3.25( \pm 1.24)$ in RIFLE serum creatinine group $\left(\mathrm{S}_{\mathrm{cr}}\right)$ and $2.84( \pm 1.03)$ in RIFLE combined group $\left(\mathrm{S}_{\mathrm{cr}}+\mathrm{UO}\right)$. It indicates less time needed $(3.25$ \pm 1.24 days vs $2,84 \pm 1.03$ ) to diagnose AKI in RIFLE $\mathrm{S}_{\mathrm{Cr}}+\mathrm{UO}$ group than in RIFLE $\mathrm{S}_{\mathrm{Cr}}$ groups ( $\mathrm{p}$-value $<0.001$ ).

Table 111 shows numbers of AKI patients and non AKI patients diagnosed from day 1 to day 6 (total seven days) using RIFLE combined $\mathrm{S}_{\mathrm{Cr}}+\mathrm{UO}$ criteria.

In our study, the use of RIFLE $\mathrm{S}_{\mathrm{Cr}}$ instead of RIFLE $\mathrm{S}_{\mathrm{Cr}}+\mathrm{UO}$ resulted in lower incidence of AKI on $1^{\text {st }}$ day of diagnosis 118 vs. $188,(79.7 \%$ vs. $50 \%$ ) (Table; IV), (p <0.001, statistically highly significant. But with progression of days in ICU the incidences became same on $6^{\text {th }}$ and $7^{\text {th }}$ day in ICU, total 97 patients $(96.0 \%)$ and total 91 patients $(98.3 \%)$ respectively, pvalue non-significant. Which means that the patients who were considered to be Non- AKI using patients RIFLE $\mathrm{S}_{\mathrm{Cr}}$ criteria, on the $1^{\text {st }}$ day in ICU, subsequently became AKI on $6^{\text {th }}$ and $7^{\text {th }}$ days. So, RIFLE $\mathrm{S}_{\mathrm{Cr}}$ criteria delayed the diagnosis of AKI in terms of days.

According to RIFLE $\mathrm{S}_{\mathrm{Cr}}+\mathrm{UO}$ criteria, total 48 patients $(20.33 \%)$ were Non- AKI on $1^{\text {st }}$ day in ICU. RIFLE $\mathrm{S}_{\mathrm{Cr}}+\mathrm{UO}$ criteria and RIFLE $\mathrm{S}_{\mathrm{Cr}}$ criteria both, diagnosed total 06 patients $(6.18 \%)$ as having Non-AKI on final day (day-6) in ICU (Table V). RIFLE $\mathrm{S}_{\mathrm{Cr}}$ group has significantly higher no. of Non-AKI patients in comparison to RIFLES $\mathrm{S}_{\mathrm{Cr}}+\mathrm{UO}$ group (p- value $<0.001$ ). Patients who did not have AKI on $1^{\text {st }}$ day using RIFLE $\mathrm{S}_{\mathrm{Cr}}$ criteria and these patients were indeed diagnosed as having AKI based on RIFLE $\mathrm{S}_{\mathrm{Cr}}+\mathrm{UO}$. Only 06 patients $(6.2 \%)$, remained Non-AKI on day-6 using RIFLES $\mathrm{Cr}$ criterion, there is no significant difference between RIFLE $\mathrm{S}_{\mathrm{Cr}}$ Non-AKI and RIFLE $\mathrm{S}_{\mathrm{Cr}}+\mathrm{UO}$ Non-AKI patients on final day in ICU.

Table Vl, shows severity grades in both the groups, RIFLE combined $\mathrm{S}_{\mathrm{Cr}}+\mathrm{UO}$ criteria and RIFLE $\mathrm{S}_{\mathrm{Cr}}$ criteria. In terms of AKI-R , AKI-I and AKI -F severity criteria, combined group out numbers Rifle $\mathrm{S}_{\mathrm{cr}}$ group and they are statistically significant.

In the present study, ICU mortality is 73 (30.93\%). Among the dead patients RIFLE $\mathrm{S}_{\mathrm{Cr}}$ AKI was 39 (53.42\%) and RIFLE $\mathrm{S}_{\mathrm{Cr}}$ Non- AKI was 34 (46.57\%). RIFLE $\mathrm{S}_{\mathrm{Cr}}+\mathrm{UO}$ AKI mortality was 55 (75.34) and Non-AKI was 18(24.65\%). (Table VII, VIII)

Table IX, compares outcomes and mortality rates among AKI and non AKI patients according to both RIFLE combined $\mathrm{S}_{\mathrm{Cr}}+\mathrm{UO}$ criteria and RIFLE $\mathrm{S}_{\mathrm{Cr}}$ criteria.

Table X, compares mortality rates among RIFLE combined $\mathrm{S}_{\mathrm{Cr}}+\mathrm{UO}$ criteria and RIFLE $\mathrm{S}_{\mathrm{Cr}}$ criteria. It shows that non AKI diagnosed by $\mathrm{SCr}$ alone has more death compared to non AKI diagnosed by combined criteria. ( $p$ 0.0003).

The question arises of whether at least some of the oliguric patients without an increase in SCr actually did have AKI, or whether they were oliguric for some other reason (for example, their hydration status ${ }^{15}$.

Hydration status of the patient, at the time of AKI diagnosis is an important predictor of mortality from $\mathrm{AKI}^{16}$. Fluid balance is positive in 184 patients and negative only in 52 patients. Among negative fluid balance patients, RIFLE $\mathrm{S}_{\mathrm{Cr}}$ group had $19(16.1 \%)$ patients and RIFLE $\mathrm{S}_{\mathrm{Cr}}+\mathrm{UO}$ group had 43 $(22.87 \%)$ patients (Table XI).

Among the co-morbities we found that significantly higher no of patients of RIFLE $\mathrm{S}_{\mathrm{Cr}}+\mathrm{UO}$ group had hypertension and diabetes, p- value $<0.001$. Other co-morbities like cancer, chronic heart failure, use of vasoactive drugs, had no significant difference between the groups (Table Xll).

We have observed few common etiology of AKI and their distribution among RIFLE serum creatinine $\left(\mathrm{S}_{\mathrm{cr}}\right)$ and RIFLE Combined $\left(\mathrm{S}_{\mathrm{cr}}+\mathrm{UO}\right)$ AKI group. Most common cause was sepsis, total 145 patients $(77.9 \%)$. Next common cause is hypovolemia, total patient is $85(44.9 \%)$. RIFLE serum creatinine $\left(\mathrm{S}_{\mathrm{cr}}\right)$ AKI is $37.8 \%$ and RIFLE Combined $\left(\mathrm{S}_{\mathrm{cr}}+\mathrm{UO}\right)$ AKI is $36.1 \%$. There is no significant difference in incidence of drug induced causes, sepsis, hypovolemia, cardiogenic shock, hepatorenal syndrome between RIFLE serum creatinine $\left(\mathrm{S}_{\mathrm{cr}}\right)$ and RIFLE Combined $\left(\mathrm{S}_{\mathrm{cr}}+\mathrm{UO}\right)$ AKI group (Table XIIl).

There are several studies that compared two components of RIFLE namely the serum creatinine and urine output (UO). A comparison of RIFLE with and without urine output criteria for acute kidney injury in critically ill patients by Wlodzimirow KA et all. ${ }^{17}$ They diagnosed AKI using both RIFLE methods and compared the effects on time to AKI diagnosis, AKI incidence and AKI severity. This was a prospective observational cohort study during four months in adult critically ill patients admitted to the ICU for at least 48 hours. During the first week patients were scored daily for AKI according to RIFLE SCr+UO and RIFLE SCr. They assessed urine output hourly and fluid balance daily. The baseline $\mathrm{SCr}$ was estimated if a recent pre-ICU admission $\mathrm{SCr}$ was unknown. Based on the two RIFLE methods for each patient they determined time to AKI diagnosis (AKI-0) and maximum RIFLE grade. In their study they enrolled two hundred sixty patients, the two RIFLE methods resulted in statistically significantly different outcomes for incidence of AKI, diagnosis of AKI for individual patients, distribution of AKI-0 and distribution of the maximum RIFLE grade. Discarding the RIFLE urine criteria for AKI diagnosis significantly underestimated the presence and grade of AKI on admission and during the first ICU week $(\mathrm{P}<0,001)$ and significantly delayed the diagnosis of AKI $(\mathrm{P}<0.001)$. Based on RIFLE $\mathrm{S}_{\mathrm{Cr}} 45$ patients had no AKI on admission but subsequently developed AKI. In 24 of these patients (53\%) AKI would have been diagnosed at least one day earlier if the RIFLE urine criteria had been applied. Mortality rate in the AKI population was $38 \%$ based on RIFLES Cr and $24 \%$ based on RIFLES $\mathrm{S}_{\mathrm{Cr}}+\mathrm{UO}(\mathrm{P}=0.02)$. The use of RIFLE without the urine criteria significantly underscores the incidence and grade of AKI, significantly delays the diagnosis of AKI and is associated with higher mortality.

Thare are few studies which compared different diagnostic criteria of acute kidney injury in critically ill patients. ${ }^{18-20}$ 


\section{Conclusion}

The two RIFLE methods resulted in statistically significant different outcomes for incidence of AKI. We found their incidence become same after 4 days in ICU stay, during our seven days of follow up. We have also seen differences between two groups in maximum RIFLE grade. RIFLE $\mathrm{S}_{\mathrm{Cr}}$ group has significantly higher no. of Non-AKI and less severe AKI, e.g. RIFLE risk group, in comparison to RIFLE $\mathrm{S}_{\mathrm{Cr}}+\mathrm{UO}$ group, p- value $<0.001$. RIFLE $\mathrm{S}_{\mathrm{Cr}}+\mathrm{UO}$ group has significantly higher no. of more severe AKI, e.g. AKI injury and AKI failure.

The present study concludes that RIFLE serum creatinine criterion $\left(\mathrm{S}_{\mathrm{Cr}}\right)$ delays the diagnosis of $\mathrm{AKI}$ in comparison to RIFLE serum creatinine and urine output criteria combined (Scr+UO). AKI should be graded using both the criteria of RIFLE serum creatinine and urine output criteria combined $\left(\mathrm{S}_{\mathrm{Cr}}+\mathrm{UO}\right)$. Urine output should not be underestimated in AKI diagnosis in ICU patients. So, hourly urine output is an important marker in diagnosis of AKI in ICU patients.

\section{Limitation:}

We recognize the limitations of our study. Our study is single-centred, including a limited number of study patients. Patients' $\mathrm{S}_{\mathrm{Cr}}$ were measured daily, while urine output was measured hourly. More frequent $\mathrm{S}_{\mathrm{Cr}}$ measurements may result in earlier detection of AKI. Although we recorded fluid status, we did not evaluate whether our patients received diuretics. However, although the use of diuretics is common practice worldwide, their use is not explicitly addressed in the RIFLE criteria. We did not correct $\mathrm{S}_{\mathrm{Cr}}$ for hemo dilution. A positive fluid balance may cause dilution of $\mathrm{S}_{\mathrm{Cr}}$ and, therefore, a delay in the diagnosis based on RIFLE $\mathrm{S}_{\mathrm{Cr}}$.

\section{References}

1. Singbartl K, Kellum, JA. AKI in the ICU: definition, epidemiology, risk stratification, and outcomes. Journal of Kidney International .2012; 81(9):819-825.

2. Biesen WV, Vanholder R and Lameire N. Defining Acute Renal Failure: RIFLE and Beyond. CJASN November 2006, 1 (6) 1314-1319; DOI: https://doi.org/10.2215/CJN.02070606

3. Murugan R, Kellum JA. Acute kidney injury: what's the prognosis? Journal of Nature Reviews Nephrology.2011;7(4):209-217

4. Mishra J., Ma Q., Prada A., Mitsnefes M., Zahedi K., Yang, J. et al.Identification of neutrophil gelatinase-associated lipocalin as a novel early urinary biomarker for ischemic renal injury. Journal of American Society of Nephrology.2003; 14: 2534-2543.

5. Ichimura T, BonventreJV,Bailly V, Wei H., Hession CA, Cate RL et al. Kidney injury molecule-1 (KIM-1), a putative epithelial cell adhesion molecule containing a novel immunoglobulin domain, is up-regulated in renal cells after injury. Journal of Biological Chemistry.1998; 273(7):4135-4142.
6. Parikh CR, Jani A, Melnikov VY, Faubel S, Edelstein CL. Urinary interleukin-18 is a marker of human acute tubular necrosis. American Journal of Kidney Disease.2004; 43(3):405-414.

7. Ahlström A, Tallgren M, Peltonen S, Pettilä V. Evolution and predictive power of serum cystatin $\mathrm{C}$ in acute renal failure. Journal of Clinical Nephrology.2004; 62(5):344-350.

8. Yamamoto T, Noiri E, Ono Y, Doi K, Negishi K, Kamijo A et al. (2007). Renal L-type fatty acid-binding protein in acute ischemic injury. Journal of American Society of Nephrology.2007;18(11):2894-2902.

9. Nechemia-Arbely Y, Barkan D, Pizov G, Shriki A, Rose-John S, Galun E et al. IL-6/IL-6R axis plays a critical role in acute kidney injury. Journal of American Society of Nephrology.2008; 19(6): 1106-1115.

10. D'Amico G, Bazzi C. Urinary protein and enzyme excretion as markers of tubular damage. Journal of Current Opinion in Nephrology and Hypertension2003; 12(6): 639-643.

11. Westhuyzen J, Endre ZH, Reece G, Reith DM, Saltissi D, Morgan TJ. Measurement of tubular enzymuria facilitates early detection of acute renal impairment in the intensive care unit. Nephrol Dial Transplant. 2003 Mar; 18(3):543-51.

12. Singer M, Deutchman CS, Seymour CW, Hari MS, Annane D, Bauer M et al. (23 February 2016). The Third International Consensus Definitions for Sepsis and Septic Shock (Sepsis-3). JAMA. 315 (8): 801-10. doi:10.1001/jama.2016.0287.

13. Knaus WA, Draper EA, Wagner DP, Zimmerman JE (1985). "APACHE II: a severity of disease classification system". Critical Care $\quad$ Medicine. $13 \quad$ (10): doi:10.1097/00003246-198510000-00009. PMID 3928249.

14. Le Gall JR; Lemeshow S; Saulnier F (1993). A new Simplified Acute Physiology Score (SAPS II) based on a European/North American multicenter study. JAMA. 270 (24): 2957-63 doi:10.1001/jama.1993.03510240069035.

15. Macedo E., Malhotra R., Bouchard J., Wynn SK., Mehta RL. Oliguria is an early predictor of higher mortality in critically ill patients. Journal of Kidney International.2011; 80:760-767.

16. Chertow GM, Burdick E, Honour M, Bonventre JV, Bates DW. Acute kidney injury, mortality, length of stay, and costs in hospitalized patients. J Am SocNephrol. 2005 Nov; 16(11):3365-70.

17. Wlodzimirow KA, Abu-Hanna A, Slabbekoorn M, Chamuleau RA, Schultz MJ, Bouman CS A comparison of RIFLE with and without urine output criteria for acute kidney injury in critically ill patients. Crit Care. 2012 Oct 18; 16(5):R200. doi: 10.1186/cc11808.

18. Singbartl K., Kellum, JA. AKI in the ICU: definition, epidemiology, risk stratification, and outcomes. Kidney International2012; 81(9) 819-825.

19. Xuying Luo, Li Jiang, Bin Du, Ying Wen, Meiping Wang, and Xiuming $\mathrm{Xi}$; A comparison of different diagnostic criteria of acute kidney injury in critically ill patients ; Crit Care. 2014; 18(4): R144.

20. Bagshaw BS, George C, Bellomo R, A comparison of the RIFLE and AKIN criteria for acute kidney injury in critically ill patient Nephrology Dialysis Transplantation, May 2008. 23(5);1569-1574, doi.org/10.1093/ndt/gfn009 